\title{
The Effectiveness of Multimedia Application in Teaching Vocabularies for the Children in Rural Area
}

\author{
Norhayati ${ }^{1}$, Nang Randu Utama ${ }^{2}$ \\ ${ }^{1}$ STMIK PALANGKARAYA, Palangka Raya \\ ${ }^{2}$ POLTEKKES KEMENKES, Palangka Raya \\ 1'inoynorhayati@gmail.com, 2nangranduutama@gmail.com
}

\begin{abstract}
Multimedia usage has been becoming a good trend in language learning. The collaboration of application developers and educational practitioners has created many multimedia applications with various learning purposes. This study was purposed to determine the effectiveness of multimedia applications to improve students' vocabularies. The interesting variable of this study was the subject. The subject is the children who live in the village near Rungan river bank, namely Petuk Katimpun village. It is located in a rural area, located about 25 kilometers from Palangka Raya city. Those children have limited access to the latest gadgets or e-learning applications, so the children got new experiences of learning language by conducting this study. The study results showed some positive effects of the use of multimedia applications for children in basic language learning. The children can recall their memory perfectly when they were tested on a vocabulary quiz. The children were also can imitate the pronunciation of the words given $80 \%$ correctly. However, for dictation, the children still found it difficult to write down the words they heard correctly. Overall, the multimedia application usage for teaching vocabularies is very beneficial for the children.
\end{abstract}

Keyword: Multimedia, vocabularies, children, rural area

\section{INTRODUCTION}

The use of multimedia in language learning has become broadly common nowadays. In the advanced country, multimedia has become the main media in language teaching. Mthethwa (2018) stated that multimedia diversifies the approach to teaching vocabulary; no one approach could be comprehensive, sufficient, and conclusive in teaching the same. However, the use of the multimedia application has a positive impact on the children's learning experience. An experimental study conducted by Shi (2017) for Chinese students showed clear evidence of the effectiveness of multimedia application in the development of vocabulary acquisition. A study case for Junior High School students in Aceh was also conducted by Rahmi (2014). According to the students' competencies, the study stated that the teacher builds up a new atmosphere in the teaching-learning process using pint text in reading, 
speaking, writing, and vocabulary. The multimedia usage as teaching vocabulary media has positively affected students' understanding and students' attitude in learning English.

Multimedia is the combination of text, sound, graphics, video, or animation. In the language teaching field, it is commonly used to teach vocabulary. Most of the language learning software these days consists of hypermedia (Fotos \& Browne, 2004). The teaching of vocabularies becomes much more interesting by using colorful pictures and animations. Some of the media also had audio features in them. So the new words are taught by how they are read and seen and how they are pronounced.

The basic vocabulary of a language is the core of its lexicon. It comprises those words that are most useful for the speaker and hearer because they are most frequent in texts of different genres, designate concepts central to human life, suffice to paraphrase and explain all the other words of the lexicon.

The criteria for selecting the basic vocabulary are of two different kinds:

a. Quantitative criteria: The items are the most frequent ones by certain standards. Moreover, their dispersion (distribution over styles, registers, genres, etc.) is equal.

b. Semantic criteria: The items represent central lexical fields like designations of persons and important animals, color terms, kin terms, body part terms, etc.;

c. Furthermore, within each of these fields, the most basic lexemes are chosen in terms of lexical field structure.

The process of vocabulary acquisition and teaching takes a special character when young learners are the recipients of the instruction. The particular cognitive stage of children learning a foreign language influences their use and acquisition of vocabulary. Examining the lexical errors produced by these young learners provides us with an insight into that vocabulary acquisition process and reveals what areas of the foreign language lexis do young learners have problems with when writing in English. In this study, the vocabularies that would be taught were basic vocabulary related to the environment around the children.

The children who live in the cities have a better chance to learn by using multimedia applications. The electric power and devices are easily accessed. In comparison, the children who live in rural areas have limited access to learning devices. The learning 
media that they most commonly use are books. By carrying out this study, it is hoped that it can provide new learning experiences. Petak Katimpun village is located about 25 kilometers from the city center. Most of the people work as fishermen. Due to the village's location and the low income of the people, the children have limited access to learn by using technology such as multimedia applications.

\section{METHODS}

This study is experimental research. Experimental research is a study that strictly adheres to a scientific research design. It includes a hypothesis, a variable that the researcher can manipulate, and variables that can be measured, calculated, and compared. Most importantly, experimental research is completed in a controlled environment. The researcher collects data, and the results will either support or reject the hypothesis.

This study was conducted in order to find out the answers to the following questions:

1. Is the use of multimedia in language learning have an effect of increasing the understanding of new words for the students in a rural area?

2. Does multimedia in language learning affect the interest in learning English for the students in a rural area?

2.1. The subject of the study

The subject was the 20 children aged 7 to 10 years old who live in Petuk Katimpun village.

2.2. The process of collecting the data

The study was conducted for six months or one semester. In the first phase, the children were taught about the vocabulary of the surrounding object. The teaching was used conventional media, printed pictures, and texts. During the learning process, the children were observed to react toward the learning activity and learning media used. After that, the children were given a test to find out their understanding of the material given.

For the second phase, the children were taught about the same material, vocabularies of surrounding objects, while the teaching media used was the 
multimedia application. While conducting the learning process, the children were observed. The last step was conducting the test. Both of the observation results were then analyzed and compared. It was also implemented for the result of the test.

\section{RESULTS AND DISCUSSION}

In this section, the statistical description of the experimental test will be presented. The statement items are used to measure the children's interest in the multimedia application in language learning.

The criteria of interest are shown on the data from the questionnaire, attitudes as to possible learning efficacy, and attitudes to the application's potential as a self-study tool. The percentage form of the results is presented in Table 1 below.

Table 1. Subjects' general attitudes toward multimedia application in percentage

\begin{tabular}{|l|c|c|c|c|c|}
\hline \multicolumn{1}{|c|}{ Criteria } & $\begin{array}{c}\text { Strongly } \\
\text { agree }\end{array}$ & Agree & Disagree & $\begin{array}{c}\text { Strongly } \\
\text { disagree }\end{array}$ & $\begin{array}{c}\text { No } \\
\text { Reply }\end{array}$ \\
\hline A waste of time & 1,8 & 6,5 & 5,6 & 40,8 & 45,3 \\
\hline Boring & 3,7 & 2,1 & 12,1 & 49,4 & 32,7 \\
\hline Complicated & 1,9 & 12 & 11,2 & 51,4 & 23,5 \\
\hline Difficult & 0 & 2,6 & 16,1 & 48,6 & 32,7 \\
\hline Easy & 30,9 & 42 & 22,3 & 2,7 & 2,1 \\
\hline Fun & 32,7 & 39,3 & 22,4 & 2,4 & 3,2 \\
\hline Interesting & 41,8 & 40,5 & 10,3 & 4,2 & 3,2 \\
\hline Motivating & 44,5 & 28 & 19,8 & 3,5 & 4,2 \\
\hline Not enjoyable & 0,9 & 2,9 & 51,5 & 42,5 & 2,2 \\
\hline Simple & 35,7 & 52,3 & 6,3 & 2,9 & 2,8 \\
\hline Useful & 46,5 & 44 & 5 & 0 & 4,5 \\
\hline
\end{tabular}

Table 1 showed that students' general attitudes towards using the multimedia application were significantly favorable. According to the responses to the statements, more than $80 \%$ reacted positively, and the application's "usefulness," "ease," and "fun" characteristics typify the most positive reactions.

The score of the test of the first and the second phase are presented in Table 2 below.

Table 2. Subjects' score on the test 


\begin{tabular}{|c|c|c|c|}
\hline Participants & Score of first phase & Score of second phase & $\begin{array}{c}\text { Percentage increase in } \\
\text { test score }\end{array}$ \\
\hline $\mathrm{n}-1$ & 65 & 70 & 92,86 \\
\hline $\mathrm{n}-2$ & 65 & 70 & 92,86 \\
\hline $\mathrm{n}-3$ & 65 & 70 & 92,86 \\
\hline $\mathrm{n}-4$ & 70 & 80 & 87,50 \\
\hline $\mathrm{n}-5$ & 75 & 90 & 83,33 \\
\hline $\mathrm{n}-6$ & 60 & 75 & 66,67 \\
\hline $\mathrm{n}-7$ & 60 & 75 & 80,00 \\
\hline $\mathrm{n}-8$ & 75 & 90 & 83,33 \\
\hline $\mathrm{n}-9$ & 75 & 90 & 83,33 \\
\hline $\mathrm{n}-10$ & 60 & 75 & 66,67 \\
\hline $\mathrm{n}-11$ & 60 & 75 & 80,00 \\
\hline $\mathrm{n}-12$ & 75 & 95 & 78,95 \\
\hline $\mathrm{n}-13$ & 75 & 95 & 52,63 \\
\hline $\mathrm{n}-14$ & 70 & 80 & 87,50 \\
\hline $\mathrm{n}-15$ & 70 & 80 & 87,50 \\
\hline $\mathrm{n}-16$ & 60 & 75 & 80,00 \\
\hline $\mathrm{n}-17$ & 60 & 70 & 85,71 \\
\hline $\mathrm{n}-18$ & 75 & 95 & 78,95 \\
\hline $\mathrm{n}-19$ & 75 & 95 & 78,95 \\
\hline $\mathrm{n}-20$ & 60 & 85 & 70,59 \\
\hline & & & \\
\hline
\end{tabular}

It can be seen in table 2 that there was a significant increase. It was around $80.51 \%$, toward the comparison of the score of the first and second phases.

The finding of this result was also confirmed by Rahimi \& Allahyari (2019) that revealed multimedia-assisted vocabulary learning strategy instruction had a significant effect on promoting language learners' general use of vocabulary learning strategies.

\section{CONCLUSIONS}

Based on the data and the results of the discussion in the previous section, we concluded that:

1. The vocabularies that were taught to children were basic vocabularies that have the theme of surrounding objects.

2. Children showed positive responses to multimedia applications used in vocabulary learning activities. 
3. Children responded that the material taught using multimedia applications was easier to be remembered and to be understood.

4. Children agreed that using multimedia applications in learning new vocabulary was very easy and very useful for them.

5. Besides understanding the meaning of new sentences, children can also learn to say vocabulary by imitating the sounds they use through multimedia applications.

The use of technology in education, especially in teaching media, is very beneficial for both children and the learning process itself. IT experts are expected to always work together with education practitioners to create and develop innovative products to be used optimally for language learning activities. Education practitioners are expected to use multimedia applications more often for children who live in rural areas. It is important that these children were not far behind compared to children who live in the cities.

\section{REFERENCES}

Fotos, S., \& Browne, C. M. (Eds.). (2004). New Perspectives on CALL for Second Language Classrooms (1st ed.). Routledge. https://doi.org/10.4324/9781410610775

Mthethwa, P. (2018). Teaching Vocabulary Using Multimedia: The Case of U.S. International Students. . 8. 10.18844/gjflt.v8i2.3190. Global Journal of Foreign Language Teaching, 08(02), 68-75. https://doi.org/https://doi.org/10.18844/gjflt.v8i2.3190

Rahimi, M., \& Allahyari, A. (2019). Effects of Multimedia Learning Combined With Strategy-Based Instruction on Vocabulary Learning and Strategy Use. SAGE Open, 9(2). https://doi.org/10.1177/2158244019844081

Rahmi, R. (2014). The Used of Multimedia in English Language Teaching; (a Case Study at SMP Negeri 2 Mesjid Raya, Aceh Besar). Getsempena English Education Journal, 01(02). https://doi.org/https://doi.org/10.46244/geej.v1i2.677

Shi, X. (2017). Application of Multimedia Technology in Vocabulary Learning for Engineering Students. International Association of Online Engineering IJET, 12(01), 21-31. https://core.ac.uk/download/pdf/276538174.pdf 